\title{
Anticancer activity assessment of two novel binuclear platinum (II) complexes.
}

Mohammad Bagher Shahsavani ${ }^{1,2}$, Shamseddin Ahmadi ${ }^{1}$, Marzieh Dadkhah Aseman ${ }^{3}$, S. Masoud Nabavizadeh ${ }^{3}$, Mehdi Rashidi ${ }^{3}$, Zahra Asadi ${ }^{3}$, Nasrollah Erfani ${ }^{4}$, Atieh Ghasemi ${ }^{5}$, Ali Akbar Saboury ${ }^{5}$, Ali Niazi ${ }^{6}$, Aminollah Bahaoddini $^{7}$, Reza Yousefi ${ }^{2 *}$

${ }^{1}$ Department of Biological Science and Biotechnology, Faculty of Science, University of Kurdistan, Sanandaj, Iran

${ }^{2}$ Protein Chemistry Laboratory (PCL), Department of Biology, College of Sciences, Shiraz University, Shiraz, Iran

${ }^{3}$ Department of Chemistry, College of Sciences, Shiraz University, Shiraz, Iran

${ }^{4}$ Institute for Cancer Research (ICR), School of Medicine, Shiraz University of Medical Sciences, Shiraz, Iran

${ }^{5}$ Institute of Biochemistry and Biophysics (IBB), University of Tehran, Tehran, Iran

${ }^{6}$ Institute of Biotechnology, Shiraz University, Shiraz, Iran

${ }^{7}$ Department of Biology, College of Sciences, Shiraz University, Shiraz, Iran

Corresponding Authors: Reza Yousefi (PhD), Tel.: +98 7136137665; Fax: +98 7132280916.

E-mail address: ryousefi@shirazu.ac.ir 


\section{Abstract}

In the current study, two binuclear Pt (II) complexes, containing cis, cis-[ $\mathrm{Me}_{2} \mathrm{Pt}(\mu-\mathrm{NN})$ ( $\mu$-dppm) $\left.\mathrm{PtMe}_{2}\right](\mathbf{1})$, and cis,cis-[Me $2 \mathrm{Pt}(\mu-\mathrm{NN})\left(\mu\right.$ dppm) $\left.\operatorname{Pt}\left(\left(\mathrm{CH}_{2}\right)_{4}\right)\right]$ (2) in which $\mathrm{NN}=$ phthalazine and dppm = bis (diphenylphosphino) methane were evaluated for their anticancer activities and DNA/purine nucleotide binding properties. These Pt (II) complexes, with the non-classical structures, demonstrated a significant anticancer activity against Jurkat and MCF-7 cancer cell lines. The results of ethidium bromide/acridine orange staining and Caspase-III activity suggest that these complexes were capable to stimulate an apoptotic mechanism of cell death in the cancer cells. Using different biophysical techniques and docking simulation analysis, we indicated that these complexes were also capable to interact efficiently with DNA via a non-intercalative mechanism. According to our results, substitution of cyclopentane (in complex 2) with two methyl groups (in complex 1) results in significant improvement of the complex ability to interact with DNA and subsequently to induce the anticancer activity. Overall, these binuclear Pt (II) complexes are promising group of the non-classical potential anticancer agents which can be considered as molecular templates in designing of highly efficient platinum anticancer drugs.

Keywords: Anticancer drugs, Platinum complexes, Cancer cells, DNA damage, Apoptosis. 


\section{Introduction}

Since the discovery of cisplatin (cis-diamminedichloroplatinum-II) as one of the most successful anticancer drugs; thousands of new platinum complexes have been synthesized and evaluated for their anticancer properties [1-5]. Despite the fact of their sound results in cancer therapy, patients receiving platinum drugs may also experience severe side effects which subsequently limit their administration in the clinical practice [2]. The most specific side effects of platinum anticancer drugs are damage to the kidney, neurotoxicity and hearing loss [6-10]. As shown in Fig.1, while DNA is an ultimate biological target of anticancer platinum drugs, their non-specific reaction with proteins (e.g. metallothioneins, thioredoxin) and other thiol-containing molecules such as cysteine, reduced glutathione and methionine provide a pathomechanism explaining the various side effects which are generally linked with their clinical applications[4, 11].

\section{Fig. 1 to be inserted here}

While, the platinum-based anticancer drugs indicate good efficacy in treatment of a variety of cancers from different origins, they may also demonstrate a poor therapeutic index against some other types of cancer $[12,13]$. It has been suggested that the efficacy of platinum-based drugs depends not only on their capability to induce DNA damages, but also on the target cell's ability to detect and respond to the induced DNA damages [14-17]. In fact, as shown in Fig.1, the successful DNA repair attempts of the cells treated with platinum drugs is an additional basis for the resistance development against such compounds. The cellular accumulations of platinum complexes which generally occur by either passive or active uptake are known as another constraint which may have a great impact on their efficacy in the cellular level $[18,19]$. In addition, the recognition of platinum-based compounds with the drug efflux system (e.g. ATP7A/B and GS-X pump) or their metabolic inactivation by metabolizing enzymes may contribute in the attenuation of their therapeutic potentials [20]. 
Recently, many efforts have been made to introduce non-conventional structures of platinum compounds that violate their empirical structure-activity relationships. These labours have been made with the aim to overcome the above mentioned restrictions which are associated with application of the classical platinum complexes. The multinuclear Pt complexes are good example of such compounds bearing non-classical structures. These platinum complexes contain two or more linked platinum centres that can each covalently bind to DNA, and hence are talented to forming an entirely diverse range of DNA adducts compared to cisplatin which forms principally intra strand crosslink between two adjacent guanine bases. Therefore, the multi-nuclear complexes signify an absolutely new model of platinum based drugs, and seem to be a great potential as new anticancer agents $[6,21]$. In the present work, we used two binuclear platinum (II) complexes, cis, cis-[ $\mathrm{Me}_{2} \mathrm{Pt}(\mu-\mathrm{NN})(\mu-\mathrm{dppm})$ $\left.\mathrm{PtMe}_{2}\right]$ (1), and cis,cis-[Me $\left.2 \operatorname{Pt}(\mu-\mathrm{NN})(\mu \mathrm{dppm}) \operatorname{Pt}\left(\left(\mathrm{CH}_{2}\right)_{4}\right)\right]$ (2) in which $\mathrm{NN}=$ phthalazine and $\mathrm{dppm}=$ bis (diphenylphosphino) methane. These complexes are synthesized, respectively, by reaction of cis, cis- $\left[\mathrm{Me}_{2} \mathrm{Pt}\left(\mu-\mathrm{SMe}_{2}\right)\left(\mu\right.\right.$-dppm) $\left.\mathrm{PtMe} \mathrm{M}_{2}\right]$ and cis, cis- $\left[\mathrm{Me}_{2} \mathrm{Pt}(\mu-\right.$ $\left.\mathrm{SMe}_{2}\right)\left(\mu\right.$-dppm)Pt $\left.\left.\left(\mathrm{CH}_{2}\right)_{4}\right)\right]$ with 1 equiv of phthalazine, proceeded by replacement of the labile bridging $\mathrm{SMe}_{2}$ ligand with the bidentate $\mathrm{N}$-donor ligand $\mathrm{NN}[22,23]$. There are limited studies on binuclear $\mathrm{Pt}$ complexes in this area. Also, the phthalazine ligand in these complexes is not tightly connected to Pt centres and therefore it can be easily removed to give a vacant site needed for interaction with DNA. These two structurally related binuclear Pt (II) complexes were evaluated for their anticancer activities against Jurkat and MCF-7 cancer cell lines. In addition, to gain further insights into their mechanism of action, the interaction of these complexes with DNA and nucleotides (AMP, GMP) was evaluated, using different biophysical techniques. 


\section{Material and methods}

\subsection{Material}

Herring sperm DNA (hsDNA) was purchased from sigma. All other materials and reagents obtained from Sigma-Aldrich Company with the analytical grade. Experiments were carried out in $5 \mathrm{mM}$ Tris-HCl buffer containing $50 \mathrm{mM} \mathrm{NaCl}$, pH 7.4. A solution of hsDNA had a ratio of UV absorbance's more than 1.8 at 260 and $280 \mathrm{~nm}$, indicating that DNA was sufficiently free from protein [24]. The hsDNA stock solution was prepared by dissolving DNA in $5 \mathrm{mM}$ Tris- $\mathrm{HCl}$ buffer $\mathrm{pH} 7.4$, containing $50 \mathrm{mM} \mathrm{NaCl}$. This solution was stored at $4{ }^{\circ} \mathrm{C}$ and used freshly over no more than 4 days. The DNA concentration was determined by UV-Vis spectrophotometer in properly diluted samples using the molar absorption coefficient of $6600 \mathrm{M}^{-1} \mathrm{~cm}^{-1}$ at $260 \mathrm{~nm}[25]$.

\subsection{Cell line}

Jurkat (Human T cell lymphoblast cell line) and MCF-7 (breast cancer cell line) were obtained from the cell bank of Pasteur Institute of Iran. These cells were maintained in RPMI-1640 medium, supplemented with 10\% fetal bovine serum (FBS) in a humidified incubator $\left(37^{\circ} \mathrm{C}\right.$ and $\left.5 \% \mathrm{CO}_{2}\right)$.

\subsection{Methods}

\subsubsection{Synthesis of two binuclear Pt (II) complexes}

To a solution of cis,cis-[Me $\left.2 \mathrm{Pt}\left(\mu-\mathrm{SMe}_{2}\right)(\mu-\mathrm{dppm}) \mathrm{PtR}_{2}\right]\left(\mathrm{R}=\mathrm{Me}\right.$ or $\left.\left(\mathrm{CH}_{2}\right)_{4}\right)$ in acetone $(15$ $\mathrm{mL}$ ) was added phthalazine, $\mathrm{NN}$, in acetone $(5 \mathrm{~mL})$ at room temperature. The mixture was stirred for $1 \mathrm{~h}$, the solvent was then removed under reduced pressure, and the residue was triturated with ether $(3 \mathrm{~mL})$ to give final product cis,cis-[Me $\mathrm{Me}_{2} \mathrm{Pt}\left(\mu-\mathrm{SMe}_{2}\right)\left(\mu\right.$-dppm) $\left.\mathrm{PtMe}_{2}\right]$, complex 1, and cis,cis-[Me $\left.2 \operatorname{Pt}\left(\mu-\mathrm{SMe}_{2}\right)(\mu-\mathrm{dppm}) \operatorname{Pt}\left(\left(\mathrm{CH}_{2}\right)_{4}\right)\right]$, complex 2, which were 
separated and dried under vacuum [22, 23]. The obtained binuclear complexes are pure as confirmed by elemental analysis and ${ }^{1} \mathrm{H}$ and ${ }^{31} \mathrm{P}$ NMR spectroscopy.

\subsubsection{In vitro anticancer activity of binuclear Pt (II) complexes}

Cell proliferation was evaluated using a system based on tetrazolium compound [3- (4, 5dimethylthiazol-2-yl)-2, 5-diphenyltetrazolium bromide; MTT] which is reduced by living cells to yield a soluble formazan $[26,27]$. The cancer cells were grown in tissue culture flasks in an incubator, at $37^{\circ} \mathrm{C}$ in the humidified atmosphere. The incubations were done in the presence of $5 \% \mathrm{CO}_{2}$ and $95 \%$ air, being maintained in a continuous logarithmic culture in RPMI-1640. The medium was supplemented with $10 \%(\mathrm{~V} / \mathrm{V})$ heat-inactivated FBS containing 1\% penicillin/streptomycin (PENSTREP). The cells were seeded into 96-well culture plates at a cell density of $2.5 \times 10^{4}$ cells/well, with varying concentrations of each synthesized Pt (II) complex $(0-100 \mu \mathrm{M})$ and incubated for 24 and $48 \mathrm{~h}$. Four hours until the end of incubations, $25 \mu \mathrm{L}$ of sterilized MTT solution ( $5 \mathrm{mg} / \mathrm{mL}$ in PBS) was added into each well. At the end of experiment, the insoluble formazan produced was dissolved in a solution containing $10 \%$ SDS and $50 \% \mathrm{DMF}$ and incubated at $37^{\circ} \mathrm{C}$ for $1 \mathrm{~h}$ in dark. Then, the optical density (OD) was collected at a wavelength of $570 \mathrm{~nm}$ against reagent blank, with a multiwell scanning spectrophotometer (ELISA reader, Bio- Tek's ELX808, USA). The absorbance is changed as a function of concentration of the converted MTT (yellow) to purple formazan. The OD values of the studied groups were divided by the OD values of untreated controls and presented as percentage of control (as 100\%). The values of half-maximum inhibitory concentration $\left(\mathrm{IC}_{50}\right)$ were obtained from the dose-response curves [28].

\subsubsection{Caspase-3 activity assay}

Caspase activation is a cellular event associated with the onset of apoptotic death [29]. Jurkat cancer cells $\left(4 \times 10^{6}\right)$ were treated with the synthetic complexes in their corresponding 
$\mathrm{IC}_{50}$ values for various time lengths $(2,4$ and $6 \mathrm{~h})$. At the end of incubation, the cells were harvested by centrifugation for $10 \mathrm{~min}$ at $1200 \mathrm{RPM}$ and washed in cold phosphate-buffered saline (PBS). Then, the cell pellet suspended in $50 \mu \mathrm{L}$ of chilled cell lysis buffer $(50 \mathrm{mM}$ HEPES, pH 7.4, $0.1 \mathrm{mM}$ EDTA, $100 \mathrm{mM} \mathrm{NaCl}, 1 \mathrm{mM}$ DTT and 1\% Triton X-100) and corresponding supernatant collected by centrifugation at 12,000 RPM for 10 min and kept on ice. Using Bradford assay, the concentration of protein in the supernatant of cell lysate was fixed at $100 \mu \mathrm{g} / \mathrm{mL}$ in the presence of specific chromogenic substrate of Caspase-3 (AcDMQD-pNA) with the reaction buffer (50 mM HEPES, pH 7.4, 0.1 mM EDTA, $100 \mathrm{mM}$ $\mathrm{NaCl}, 10 \mathrm{mM}$ DTT and $10 \%$ glycerol) in a 96-well plate at $37{ }^{\circ} \mathrm{C}$ for $1 \mathrm{~h}$. The activity of Caspase-3 was determined by measuring OD at $405 \mathrm{~nm}$ of the released p-nitroanilide (pNA). The results were average of three independent determinations [30].

\subsubsection{Morphological assessment of apoptotic cells}

The morphological assessments of Jurkat cancer cells after treatment with the synthesized binuclear Pt (II) complexes were evaluated using AO/EB dye mix staining method [29]. Jurkat cells $\left(2.5 \times 10^{4}\right.$ cells/well $)$ were seeded into a 96 -well cell culture plate. The cells were incubated for $6 \mathrm{~h}$ with the corresponding $\mathrm{IC}_{50}$ value of each complex as 5.00 and $22.36 \mu \mathrm{M}$ for the Pt (II) complexes $\mathbf{1}$ and 2, respectively. After incubation, the cancer cells were washed with $1 \mathrm{~mL}$ cold PBS. The cancer cells were then suspended in $30 \mu \mathrm{L}$ cold PBS, containing 3 $\mu \mathrm{L}$ of $\mathrm{AO} / \mathrm{EB}$ dye mix (each dye $100 \mu \mathrm{g} / \mathrm{mL})$. The stained cell suspension $(10 \mu \mathrm{L})$ was placed on a clean microscope slide and covered with a cover glass. Also in this experiment, cisplatin was used as a positive control. The nuclear morphology of cancer cells was assessed using a fluorescence microscope (B-600TiFL, Optika, Italy) with the blue and green filters at 100, 200 and 400 magnifications[31].

\subsubsection{UV-Vis spectroscopy analysis}


The UV-Vis absorption experiments were carried out based on previous methods by keeping the concentration of hsDNA constant at $50 \mu \mathrm{M}$, while varying the Pt complexes concentration $\left(\mathrm{r}_{\mathrm{i}}=[\mathrm{complex}] /[\mathrm{DNA}]=0,0.06,0.12,0.18,0.24,0.30,0.36,0.42,0.48,0.54\right.$, 0.60). The spectra were recorded using a CE $7200 \mathrm{UV}-\mathrm{Vis}$ spectrophotometer instrument (Cecil Instruments Ltd., UK) after the samples incubated for $5 \mathrm{~min}$ in the presence of the binuclear Pt (II) complexes $\mathbf{1}$ and $\mathbf{2}$.

\subsubsection{Reaction between purine nucleotides and the synthetic Pt (II) complexes}

The absorption titration experiment of synthesized binuclear Pt (II) complexes were performed in $\mathrm{TN}$ buffer by using a fixed concentration of each complex at $20 \mu \mathrm{M}$, and increasing concentrations $(0-60 \mu \mathrm{M})$ of nucleotides (AMP and GMP) [32]. Moreover, solutions containing binuclear Pt (II) complexes and nucleotides were incubated for $5 \mathrm{~min}$ before recording their absorption spectra. Equal concentrations of the nucleotides were also added to the reference cell in order to eliminate the absorbance of nucleotide itself [28].

\subsubsection{The fluorescence intensity assessments}

The fluorescence measurements were carried out on a Carry-Eclipse spectrofluorimeter (Model Varion, Australia), while DNA solution $(40 \mu \mathrm{M})$ pre-treated with $40 \mu \mathrm{M}$ ethidium bromide (EB) for $20 \mathrm{~min}$. The emission intensities of EB-DNA in the presence of increasing concentration of each binuclear Pt (II) complex (0-32 $\mu \mathrm{M})$ were recorded between 545-700 $\mathrm{nm}$, at an excitation wavelength of $525 \mathrm{~nm}$. These experiments were carried out in $5 \mathrm{mM}$ Tris- $\mathrm{HCl}$ buffer $\mathrm{pH} 7.4$, containing $50 \mathrm{mM} \mathrm{NaCl}$ in an aqueous media. Fluorescence emission titration experiments were performed at a fixed concentration of the Pt (II) complexes $(1 \mu \mathrm{M})$ with various concentrations of DNA $(0-30 \mu \mathrm{M})$. The experiments were done in $5 \mathrm{mM}$ Tris$\mathrm{HCl}$ buffer $\mathrm{pH} 7.4$, containing $50 \mathrm{mM} \mathrm{NaCl}$ in an aqueous media. Excitation wavelength was kept constant at $260 \mathrm{~nm}$ and the emission spectra were recorded between 500-550 nm. 


\subsubsection{CD spectroscopy experiment}

The CD spectra after interaction of each binuclear Pt (II) complex with hsDNA were recorded on a JASCO (J-810) spectropolarimeter in TN buffer. Each sample was scanned in a wavelength range between 230 and $360 \mathrm{~nm}$ using $1 \mathrm{~mm}$ path cuvette. The hsDNA $(80 \mu \mathrm{M})$ was incubated with different concentrations of each complex $(0,2.4,4.8,9.6 \mu \mathrm{M})$ for $5 \mathrm{~min}$. All measurements were carried out at $298 \mathrm{~K}$ with thermostatically controlled cell holder. Each CD spectrum was the accumulation of five successive measurements. The data were expressed as molar residue ellipticity [ $\theta]$ [33].

\subsubsection{Viscosity measurement analysis}

Viscosity measurements were done using a viscometer Ostwald maintained at $25^{\circ} \mathrm{C}$ using a constant temperature bath. The DNA concentration was fixed at $100 \mu \mathrm{M}$ and flow time was measured with a digital stopwatch. The values for relative specific viscosity $\left(\eta / \eta_{0}\right)$, where $\eta_{0}$ and $\eta$ are the specific viscosity contribution of DNA in the absence $\left(\eta_{0}\right)$ and in the presence

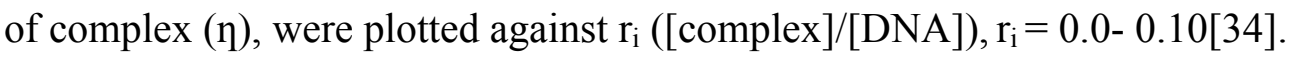

\subsubsection{Molecular docking study}

The structure of each binuclear Pt (II) complex was generated by HyperChem Professional 7.0. Then, energy minimization calculations were carried out with Density Functional Theory (DFT) method in B3LYP level. The basis set for Pt and all other atoms adjust to respectively LanL2DZ and 6-31G using Gaussian 09. The crystal structure of DNA was obtained from the protein data bank (PDB ID: 1BNA). The optimized structure of each synthetic complex and DNA was imported to the Hex 8 Cuda workspace. The parameters used for the docking process were of the following: Correlation type - Shape + Electro, FFT Mode $-3 D$, Grid Dimension - 0.6, Receptor range-180, Ligand Range-180, Twist range - 360, Translation 
Step -0.8 and Distance Range -40 . The two binuclear Pt (II) complexes were docked with DNA using the above parameters[35].

\subsubsection{Statistical analysis}

The statistical differences were determined by two- tailed student's t-test [30].

\section{Result and discussion}

\subsection{Chemistry of the synthesized binuclear Pt (II) complexes}

The poly nuclear platinum complexes represent a novel class of promising anticancer agents with potential pharmacological properties in preclinical studies[36]. In addition, the nature of cellular responses induced by these complexes is different from those caused by cisplatin and other mono nuclear platinum compounds[37]. Therefore, this innovative and structurally distinct group, breaking many structure-activity rules for platinum drugs, seems to be potentially important therapeutic agent to overcome cisplatin toxicity/resistance or to improve its efficacy. In this study, two structurally related binuclear Pt (II) complexes were synthesized and their anticancer activities against Jurkat and MCF-7 cancer cell lines were evaluated (Fig.2).

\section{Fig.2 to be inserted here}

In addition to the coordination mode and coordination number, the biological activities of Pt complexes are significantly influenced by the nature of the ligands constituting their chemical structures. The versatile and robust ligands dppm and phthalazine, possessing different coordinating abilities and a broad spectrum of biological properties, were used for the synthesis of Pt (II) complexes 1 and 2. These ligands (dppm and phthalazine) with their different biological activities, including antibacterial, antifungal, antiviral and anti- 
inflammatory properties, would increase the possible therapeutic values of the synthesized Pt (II) complexes. The platinum centres in these complexes are coordinated to the nitrogen atoms of phthalazine which has been already used in the chemical structures of a number of established medicines such as hydralazine, budralazine, azelastine, ponalrestat and zopolrestat $[38,39]$. Also, the Pt centres in these complexes are covalently connected to the phosphine atoms in dppm. The phenyl groups in dppm may facilitate their insertion between planar bases of DNA and can offer an important hydrophobic character to these complexes, facilitating their cellular uptakes[40]. In addition, each Pt centre is connected to two methyl groups in complex $\mathbf{1}$, while in complex $\mathbf{2}$, these groups are substituted with cyclopentane. Overall, these two binuclear platinum complexes indicate important variation in the chemical environment around the platinum centres which may influence their anticancer activities.

\subsection{Anticancer activity of the binuclear Pt (II) complexes}

Recently binuclear platinum complexes have received much attention due to their promising anticancer activities. These complexes which display different mode of interaction with DNA are likely important candidate to overcome the various drawbacks linked with the clinical applications of cisplatin and other mono nucleated platinum-based drugs. The results of anticancer activities of the synthesized binuclear Pt (II) complexes against Jurkat and MCF-7 cancer cells are shown in Fig.3 and Table 1. Based on the results of MTT assay, these complexes indicate significantly higher anticancer activity than cisplatin which can be explained with their efficient interaction with DNA.

\section{Fig.3 and Table 1 to be inserted here}

Also, the hydrophobic character of a numbers of phenyl groups in their structure is of beneficial for their easier cellular uptake. The non-specific reaction of Pt complexes with extra and intra cellular thiol compounds may significantly reduce their active fraction 
available for the interaction with DNA. Therefore, the bulky groups around the platinum centres may also limit the simple access of thiol-containing molecules for the reaction with these binuclear Pt (II) complexes. As shown in Fig.3 and Table 1, complex 1 demonstrates significantly higher anticancer activity than complex $\mathbf{2}$. These two complexes, as indicated in Fig.2, are different only in the ligands connected to one of their platinum centres. The substitution of two methyl groups in complex $\mathbf{1}$ with cyclopentane in complex $\mathbf{2}$, results in significant reduction of the anticancer activity against the cancer cells. This substitution, as indicated in Fig.2, has been also accompanied with the important conformational variation between these complexes which may in part contribute in the anticancer efficacy of the synthesized complexes. MTT assay is not capable to distinguish between the mechanisms of cell death pathway either apoptotic or necrotic. The dual staining with $\mathrm{AO}$ and $\mathrm{EB}$ and measuring of caspase-3 activity are two important procedures to assess the apoptotic inducing activity of these synthetic Pt complexes. AO/EB fluorescent staining allows differentiating between normal cells, early/late apoptotic cells and necrotic cells. Therefore, both methods are a qualitative and quantitative method to detect apoptosis [41, 42]. The results of changes in nuclear morphology of cancer cells after exposure to the binuclear Pt (II) complexes 1 and $\mathbf{2}$ are indicated in Figs.4A-B.

\section{Fig.4 to be inserted here}

Due to difference in the membrane integrity between necrotic and apoptosis cells, AO can penetrate the cell membrane and EB lacks this ability. Under fluorescence microscope, living cells appear green and necrotic cells stain with a nuclear morphology resembling that of viable cells. Also, apoptotic cells appear green, and morphological changes such as cell blebbing and formation of apoptotic bodies are observed[43]. As shown in Fig.4A, in the control groups (Ctrl), Jurkat cells display the morphological appearances which are representative of normal cells. Conversely, in the presence of complexes $\mathbf{1}$ and $\mathbf{2}$, the 
apoptotic cells with condensed or fragmented green nucleus were seen. The results clearly indicated that both binuclear platinum (II) complexes were capable to induce apoptosis in Jurkat cell line. Moreover, after calculating the percentages of live, apoptotic, and necrotic cells, it is suggested that complex $\mathbf{1}$ induces apoptosis more than complex $\mathbf{2}$. In order to further determine whether the synthetic complexes are capable to induce apoptotic (signalling) death, Jurkat cancer cells were exposed to the binuclear Pt (II) complexes 1 and 2, at different incubation times. At the end, the cells were harvested, washed and their lysates used for measuring the activity of Caspase-3. As shown in Fig.4C, the obtained results obviously indicated that both complexes were capable to stimulate meaningfully the activity of Caspase-3 in this cancer cells. Despite the significant ability of these complexes to induce cell death in cancer cells, the replacement of cyclopentane in complex 2 with methyl groups in complex 1 proves to have significant impact on ability of later complex to induce signalling death (apoptosis) in the cancer cells. Overall, the results as shown in Fig.4 reveal the fact that two complexes are capable to induce program cell death in Jurkat cancer cells.

\subsection{The UV-Vis assessment of interaction between binuclear Pt (II) complexes and} DNA

UV absorption measurement is one of the most constructive techniques for DNA-binding analysis of metal complexes[44]. Since the anticancer activity of platinum compounds is believed to be result of their ability to distort DNA structure; it is of highly significance to assess the interaction between the newly synthesized Pt (II) complexes and DNA. The UV absorption of DNA at $260 \mathrm{~nm}$ was monitored in the presence of increasing concentrations of the Pt complexes (Fig.5A). As shown in Fig.5A, a gradual increment in the optical density of DNA was seen as a function of complex concentration.

Fig. 5 to be inserted here 
This hyperchromic effect, as seen for the interaction of many drugs with DNA, suggests a damage in the double helix structure after the complex bound to DNA[45]. Additionally, the hyperchromic effect might be ascribed to the external contact through the electrostatic binding $[46,47]$. In other words, the hypochromic effects result from the contraction of DNA in the helix axis, as well as, from the change in DNA conformation [48, 49].

\subsubsection{The binding affinity assessment between AMP/GMP and binuclear Pt (II) complexes}

In the last decades, studies revealed a significant progress in the field of ligand recognition pattern of DNA molecules. To achieve further insights into the interaction of a metal complex to a particular site on DNA, the analysis of its interaction with low molecular building blocks of nucleic acids (e.g. AMP and GMP) seems essential. The importance of such analysis can be explained with the Pt complex-induced DNA lesions, leading to the inhibition of important enzymes which are involved in RNA transcription and DNA replication. The cease of these essential reactions at last culminates in cell death through apoptosis[32]. In addition to the binding through electrostatic interaction to the phosphate group of nucleotides, Pt complexes indicate coordination binding with the nitrogen atoms of nucleobases[50]. As reported before the interaction of pyrimidines and purines with Pt complexes mainly occurs via N7 [51, 52]. In the current study, the interaction of the synthetic complexes $\mathbf{1}$ and $\mathbf{2}$ in the presence of increasing concentration of AMP and GMP was carried out by UV-Vis absorption titration method. The results as shown in Fig.5B indicate an isosbestic point for the reaction between the $\mathrm{Pt}$ complexes and purine nucleotides, suggesting that the chemical reactions between these components are in progress. As shown in Fig.5B, the reduction in absorption intensities of the synthetic Pt (II) complexes (hypochromism) after addition of either AMP or GMP was used to compare their binding affinity. The intrinsic binding constant $\left(\mathrm{K}_{\mathrm{b}}\right)$ of the interaction 
of complexes with the nucleotides were calculated according to Eq. (1), and the obtained results indicated as Table 2.

$[\mathrm{N}] /\left(\varepsilon_{\mathrm{a}}-\varepsilon_{\mathrm{f}}\right)=[\mathrm{N}] /\left(\varepsilon_{0}-\varepsilon_{\mathrm{f}}\right)+1 / \mathrm{K}_{\mathrm{b}}\left(\varepsilon_{0}-\varepsilon_{\mathrm{f}}\right)$

where $[\mathrm{N}]$ is the concentration of nucleotide, $\varepsilon_{\mathrm{a}}$ is the ratio of absorbance/[Pt complex], $\varepsilon_{\mathrm{f}}$ is the extinction coefficient of free Pt complex and $\varepsilon_{0}$ is the extinction coefficient of the complex in the fully bound form[53].

\section{Table 2 to be inserted here}

As shown in this table, the Pt complexes demonstrate significantly higher affinity toward GMP than AMP. Furthermore, the order of their affinity toward these nucleotides was as following: 1>2.

\subsubsection{The CD assessment of interaction between binuclear Pt (II) complexes and DNA}

The CD spectroscopy is a valuable technique in detecting the changes induced in DNA conformation upon interaction with Pt complexes. This technique can be used to monitor denaturation/unwinding of DNA. In CD spectrum of DNA, the positive band is due to the base stacking $(275 \mathrm{~nm})$, while the negative one $(248 \mathrm{~nm})$ corresponds to the right-handed helicity [28]. In this study, the CD spectra of DNA were recorded in the presence of different molar ratios of binuclear Pt complexes 1 and 2.

\section{Fig.6 to be inserted here}

The changes in the CD signals of DNA, as observed upon interaction with these complexes, can be assigned to the corresponding changes in DNA morphology. As shown in Fig.6, the intensity of both negative and positive bands is significantly decreased, indicating destabilization of base-stacking and the loss of right-handed helicity. The changes observed, enlightening that DNA denaturation/unwinding is due to the strong interaction with these complexes [54]. Overall, according to the CD signals, the interaction of both complexes with 
DNA results in most significant structural alteration. Also, complex $\mathbf{1}$ indicates stronger interaction with DNA, inducing to higher extent the denaturation/unwinding of this macromolecule.

\subsubsection{Fluorescence assessment of interaction between binuclear Pt (II) complexes and DNA}

To further investigate the mode of binding of the synthetic Pt complexes with DNA, the EB displacement assay was carried out. EB is a conjugate planar molecule indicating very poor fluorescence emission intensity in its free state. When EB is specifically intercalated into the base pairs of double-stranded DNA, its fluorescence emission is greatly enhanced [55]. In this study, the emission spectra of EB-DNA were recorded in the presence of increasing concentration of each Pt complex and the obtained results are given in Fig.7A.

\section{- Fig.7 to be inserted here}

The fluorescence results revealed that when the DNA-EB titrated with the Pt complexes, no EB displacement was occurred. This finding suggests that the mode of interaction between these Pt complexes and DNA is not intercalation. This assumption can be supported with the presence of bulky ligands in these complexes, limiting their easier penetration into the spaces between adjacent DNA bases. Due to their aromatic ligands, in solution the synthetic complexes $\mathbf{1}$ and $\mathbf{2}$ indicate significant fluorescence emissions with a maximum wavelength at $522 \mathrm{~nm}$. The emission spectra of these complexes in the presence of increasing concentrations of DNA are shown in Fig.7B. Upon addition of DNA, the emission spectra of these complexes indicate a gradual quenching, suggesting that these complexes have a strong interaction with DNA. For quenching experiment, the intrinsic binding constants were calculated from Eq. (2)[56]:

$$
\log \left(\mathrm{F}_{0}-\mathrm{F}\right) / \mathrm{F}=\log \mathrm{K}_{\mathrm{b}}+\mathrm{n} \log [\mathrm{Q}]
$$


where $\mathrm{K}_{\mathrm{b}}$ and $\mathrm{n}$ are respectively the binding constant and the number of binding sites, [Q] stands for the concentration of quencher, $\mathrm{F}_{0}$ is the fluorescence intensity of free complex and $\mathrm{F}$ indicates the fluorescence intensity of complex in the presence of DNA. $\mathrm{K}_{\mathrm{b}}$ and $\mathrm{n}$ can be calculated from the double logarithm regression curve of $\log \left(\mathrm{F}_{0}-\mathrm{F}\right) / \mathrm{F}$ versus $\log [\mathrm{Q}]$ (see inset of Fig.7B) and the obtained results indicated in Table 3. As presented in Table 3, complex 1 indicates significantly larger binding constant than complex 2. Additionally, complex 1 possesses slightly larger number of binding site on DNA than complex 2 . These observations may provide scientific evidences for explaining the stronger anticancer activity of complex 1 compared to the complex 2.

\subsubsection{The viscosity measurements}

To further investigate on the binding mode of the synthetic Pt complexes with DNA, the viscosity measurements were carried out. The sensitivity of viscosity assessment to the mode of DNA binding has been already well documented[54]. The values of relative specific viscosity $\left(\eta / \eta^{\circ}\right)\left(\eta^{\circ}\right.$ and $\eta$ are the specific viscosity contributions of DNA in the absence and presence of the synthetic complexes) were plotted against $1 / R(R=[\mathrm{DNA}] /[$ complex] $)($ Fig. 8).

\section{Fig.8 to be inserted here}

As reported already, the classical intercalative mode causes an important enhancement in the viscosity of DNA solution due to increase in separation of base pairs at the intercalation sites and hence an enlargement of the overall DNA length[34]. By contrast, complexes that bind exclusively in the DNA grooves by partial and/or non-classical intercalation, typically cause less pronounced or no changes in DNA solution viscosity[54]. Our results revealed that the presence of these complexes has no obvious effect on the relative viscosity of DNA. Therefore, it is suggested that both complexes can interact to DNA with a binding different 
form the classical intercalation mode. This finding is also supported with the data of EB displacement assay (Fig.7A).

\subsubsection{Docking analysis of binding of the Pt complexes to DNA}

Molecular docking analysis was performed to explore the binding affinity and mode of interaction between the synthetic complexes and DNA. The total energy for binding interaction of complexes 1 and 2 were -167.227 and $-150.615(\mathrm{KJ} / \mathrm{mol})$, respectively. Based on the obtained values, complex 1 reveals stronger interactive force than complex 2 to DNA.

Fig.9 to be inserted here

Also, as shown in Fig.9, the docking results suggest a DNA groove binding for these Pt complexes. This finding may further support the data of EB displacement assay and viscosity assessment, suggesting the inability of these complexes for the intercalation between DNA bases. The results of docking analysis also suggest a stronger interaction for complex $\mathbf{1}$ with DNA which also supported with the data of fluorescence quenching measurement.

\section{Conclusions}

Overall, these binuclear Pt (II) complexes exhibited strong anticancer activity against Jurkat and MCF-7 cancer cell lines. Additionally, these complexes were capable to stimulate activity of Caspase-3 and to induce program cell death in cancer cells. Since DNA distortion ability of these complexes is important for their anticancer activities, different spectroscopic methods were employed to investigate their interaction with DNA and purine nucleotides (AMP and GMP). The results of UV-Vis, fluorescence and CD spectroscopy suggest that upon interaction with these complexes, the denaturation/unwinding of DNA occurs to the significant extent. The results of the EB displacement assay and viscosity measurement 
suggest that these complexes are unable to intercalate between the adjacent bases in DNA. This assumption can be supported with the data of molecular docking simulation which suggest a groove binding mode for these binuclear Pt complexes. Furthermore, the results of fluorescence quenching and molecular docking analysis suggest stronger interaction of binuclear Pt (II) complex 1 to DNA which may explain its stronger anticancer activity in comparison to the complex 2.

\section{Acknowledgments}

The financial supports of Iran National Science Foundation (grant no. 92001695) are gratefully acknowledged. Also, R.Y. and S.A. appreciatively acknowledge the financial supports of their universities research councils. 


\section{References}

[1] Gordon M, Hollander S. Review of platinum anticancer compounds, J. Med. 24 (1993) 209-265.

[2] Lebwohl D, Canetta R. Clinical development of platinum complexes in cancer therapy: An historical perspective and an update, Eur. J. Cancer 34 (1998) 1522-1534.

[3] Rosenberg B, VanCamp L, Trosko JE, Mansour VH. Platinum compounds: A new class of potent antitumour agents, Nature 222 (1969) 385-386.

[4] Weiss RB, Christian MC. New cisplatin analogues in development. A review, Drugs 46 (1993) 360-377.

[5] Wong E, Giandomenico CM. Current status of platinum-based antitumor drugs, Chem. Rev. 99 (1999) 2451-2466.

[6] Desoize B, Madoulet C. Particular aspects of platinum compounds used at present in cancer treatment, Crit. Rev. Oncol. Hematol. 42 (2002) 317-325.

[7] Florea AM, Busselberg D. Occurrence, use and potential toxic effects of metals and metal compounds, Biometals 19 (2006) 419-427.

[8] Gunes DA, Florea AM, Splettstoesser F, Busselberg D. Co-application of arsenic trioxide (as2o3) and cisplatin (cddp) on human sy-5y neuroblastoma cells has differential effects on the intracellular calcium concentration $([\mathrm{ca} 2+] \mathrm{i})$ and cytotoxicity, Neurotoxicology 30 (2009) 194-202.

[9] Shah N, Dizon DS. New-generation platinum agents for solid tumors, Future Oncol. 5 (2009) 33-42.

[10] Tsang RY, Al-Fayea T, Au HJ. Cisplatin overdose: Toxicities and management, Drug Saf. 32 (2009) 1109-1122.

[11] Perez RP, Hamilton TC, Ozols RF, Young RC. Mechanisms and modulation of resistance to chemotherapy in ovarian cancer, Cancer 71 (4 Suppl) (1993) 1571-1580.

[12] Helm L, Nicolle G, Merbach AE. Water and proton exchange processes on metal ions, Adv. Inorg. Chem. 57 (2005) 327-379.

[13] Reedijk J. Metal-ligand exchange kinetics in platinum and ruthenium complexes, Platinum Met. Rev. 52 (2008) 2-11.

[14] Eastman A. The formation, isolation and characterization of DNA adducts produced by anticancer platinum complexes, Pharmacol. Ther. 34 (1987) 155-166.

[15] Jamieson ER, Lippard SJ. Structure, recognition, and processing of cisplatin-DNA adducts, Chem. Rev. 99 (1999) 2467-2498.

[16] Kerr JF, Winterford CM, Harmon BV. Apoptosis. Its significance in cancer and cancer therapy, Cancer 73 (1994) 2013-2026. 
[17] Sedletska Y, Giraud-Panis MJ, Malinge JM. Cisplatin is a DNA-damaging antitumour compound triggering multifactorial biochemical responses in cancer cells: Importance of apoptotic pathways, Curr. Med. Chem. Anticancer Agents 5 (2005) 251-265.

[18] Jung Y, Lippard SJ. Direct cellular responses to platinum-induced DNA damage, Chem. Rev. 107 (2007) 1387-1407.

[19] Wang D, Lippard SJ. Cellular processing of platinum anticancer drugs, Nat. Rev. Drug Discov. 4 (2005) 307-320.

[20] Roat-Malone RM. Metals in medicine, Bioinorganic chemistry, John Wiley \& Sons, Inc., 2003, pp. 265-335.

[21] Cepeda V, Fuertes MA, Castilla J, Alonso C, Quevedo C, Perez JM. Biochemical mechanisms of cisplatin cytotoxicity, Anticancer Agents Med. Chem. 7 (2007) 3-18.

[22] Hoseini SJ, Nabavizadeh SM, Jamali S, Rashidi M. Uncommon solvent effect in oxidative addition of mei to a new dinuclear platinum complex containing a platina(ii)cyclopentane moiety, Eur. J. Inorg. Chem. 2008 (2008) 5099-5105.

[23] Jamali S, Nabavizadeh SM, Rashidi M. Oxidative addition of methyl iodide to a new type of binuclear platinum(ii) complex: A kinetic study, Inorg. Chem. 44 (2005) 85948601.

[24] Kennedy SD, Bryant RG. Manganese-deoxyribonucleic acid binding modes. Nuclear magnetic relaxation dispersion results, Biophys. J. 50 (1986) 669-676.

[25] Kashanian S, Gholivand MB, Ahmadi F, Taravati A, Colagar AH. DNA interaction with al-n,n'-bis(salicylidene)2,2'-phenylendiamine complex, Spectrochim. Acta A. Mol. Biomol. Spectrosc. 67 (2007) 472-478.

[26] Gao E, Zhu M, Yin H, Liu L, Wu Q, Sun Y. Synthesis, characterization, interaction with DNA and cytotoxicity in vitro of dinuclear pd(ii) and pt(ii) complexes dibridged by $2,2^{\prime}-$ azanediyldibenzoic acid, J. Inorg. Biochem. 102 (2008) 1958-1964.

[27] Matesanz AI, Pérez JM, Navarro P, Moreno JM, Colacio E, Souza P. Synthesis and characterization of novel palladium(ii) complexes of bis(thiosemicarbazone). Structure, cytotoxic activity and DNA binding of pd(ii)-benzyl bis(thiosemicarbazonate), J. Inorg. Biochem. 76 (1999) 29-37.

[28] Jamshidi M, Yousefi R, Nabavizadeh SM, Rashidi M, Haghighi MG, Niazi A, et al. Anticancer activity and DNA-binding properties of novel cationic pt(ii) complexes, Int. J. Biol. Macromol. 66 (2014) 86-96.

[29] Weber B, Serafin A, Michie J, Van Rensburg C, Swarts JC, Bohm L. Cytotoxicity and cell death pathways invoked by two new rhodium-ferrocene complexes in benign and malignant prostatic cell lines, Anticancer Res. 24 (2004) 763-770.

[30] Mohammadi R, Yousefi R, Aseman MD, Nabavizadeh SM, Rashidi M. DNA binding and anticancer activity of novel cyclometalated platinum (ii) complexes, Anticancer Agents Med. Chem. 15 (2015) 107-114. 
[31] Saydam G, Aydin HH, Sahin F, Selvi N, Oktem G, Terzioglu E, et al. Involvement of protein phosphatase $2 \mathrm{a}$ in interferon-alpha-2b-induced apoptosis in k562 human chronic myelogenous leukaemia cells, Leuk. Res. 27 (2003) 709-717.

[32] Tabassum S, Khan RA, Arjmand F, Juvekar AS, Zingde SM. Synthesis of carbohydrateconjugate heterobimetallic cu(ii)-sn(2)(iv) and $\mathrm{zn}$ (ii)-sn(2)(iv) complexes; their interactions with ct DNA and nucleotides; DNA cleavage, in-vitro cytotoxicity, Eur. J. Med. Chem. 45 (2010) 4797-4806.

[33] Divsalar A, Saboury AA, Yousefi R, Moosavi-Movahedi AA, Mansoori-Torshizi H. Spectroscopic and cytotoxic studies of the novel designed palladium(ii) complexes: Blactoglobulin and k562 as the targets, Int. J. Biol. Macromol. 40 (2007) 381-386.

[34] Liu Y-C, Chen Z-F, Song X-Y, Peng Y, Qin Q-P, Liang H. Synthesis, crystal structure, cytotoxicity and DNA interaction of 5,7-dibromo-8-quinolinolato-lanthanides, Eur. J. Med. Chem. 59 (2013) 168-175.

[35] Alex Mathew J NRN. Docking studies on anticancer drugs for breast cancer using hex, Lect. Notes Eng. Comput. Sci. 1 (2009) 250-253.

[36] Wheate NJ, Collins JG. Multi-nuclear platinum complexes as anti-cancer drugs, Coord. Chem. Rev. 241 (2003) 133-145.

[37] Abu-Surrah AS, Kettunen M. Platinum group antitumor chemistry: Design and development of new anticancer drugs complementary to cisplatin, Curr. Med. Chem. 13 (2006) 1337-1357.

[38] Hoseini SJ, Mohamadikish M, Kamali K, Heinemann FW, Rashidi M. Organoplatinum complexes containing bis(diphenylphosphino)amine as ligand: Uncommon case of $\mathrm{n}-\mathrm{h}$. . I-pt hydrogen bonding, Dalton Trans (2007) 1697-1704.

[39] Zhang QR, Xue DQ, He P, Shao KP, Chen PJ, Gu YF, et al. Synthesis and antimicrobial activities of novel 1,2,4-triazolo [3,4-a] phthalazine derivatives, Bioorg. Med. Chem. Lett. 24 (2014) 1236-1238.

[40] Yousefi R, Aghevlian S, Mokhtari F, Samouei H, Rashidi M, Nabavizadeh SM, et al. The anticancer activity and hsa binding properties of the structurally related platinum (ii) complexes, Appl. Biochem. Biotechnol. 167 (2012) 861-872.

[41] Biffl WL, Moore EE, Moore FA, Barnett CC, Jr. Interleukin-6 delays neutrophil apoptosis via a mechanism involving platelet-activating factor, J. Trauma. 40 (1996) 575579 .

[42] Carmichael J, Mitchell JB, DeGraff WG, Gamson J, Gazdar AF, Johnson BE, et al. Chemosensitivity testing of human lung cancer cell lines using the mtt assay, Br. J. Cancer 57 (1988) 540-547.

[43] Kuan Liu P-cL, Run Liu, Xing Wu. Dual ao/eb staining to detect apoptosis in osteosarcoma cells compared with flow cytometry, Med. Sci. Monit. Basic Res. 21 (2015) $15-20$. 
[44] Wang Q, Yang ZY, Qi GF, Qin DD. Synthesis, crystal structure, antioxidant activities and DNA-binding studies of the $\ln ($ iii) complexes with 7-methoxychromone-3carbaldehyde-(4'-hydroxy) benzoyl hydrazone, Eur. J. Med. Chem. 44 (2009) 2425-2433.

[45] Shahabadi N, Kashanian S, Fatahi A. Identification of binding mode of a platinum (ii) complex, ptcl(2)(dip), and calf thymus DNA, Bioinorg. Chem. Appl. 2011 (2011) 687571.

[46] Cox PJ, Psomas G, Bolos CA. Characterization and DNA-interaction studies of 1,1dicyano-2,2-ethylene dithiolate ni(ii) mixed-ligand complexes with 2-amino-5-methyl thiazole, 2-amino-2-thiazoline and imidazole. Crystal structure of [ni(i-mnt)(2a-5mt)(2)], Bioorg. Med. Chem. 17 (2009) 6054-6062.

[47] Pasternack RF, Gibbs EJ, Villafranca JJ. Interactions of porphyrins with nucleic acids, Biochemistry 22 (1983) 5409-5417.

[48] Li Q, Yang P, Wang H, Guo M. Diorganotin(iv) antitumor agent. (c2h5)2sncl2 (phen)/nucleotides aqueous and solid-state coordination chemistry and its DNA binding studies, J. Inorg. Biochem. 64 (1996) 181-195.

[49] Shi S, Liu J, Li J, Zheng KC, Huang XM, Tan CP, et al. Synthesis, characterization and DNA-binding of novel chiral complexes delta- and lambda-[ru(bpy)21]2+ $(1=0$-mopip and p-mopip), J. Inorg. Biochem. 100 (2006) 385-395.

[50] Kartalou M, Essigmann JM. Recognition of cisplatin adducts by cellular proteins, Mutat. Res. 478 (2001) 1-21.

[51] Howerton SB, Nagpal A, Williams LD. Surprising roles of electrostatic interactions in DNA-ligand complexes, Biopolymers 69 (2003) 87-99.

[52] Kelland L. The resurgence of platinum-based cancer chemotherapy, Nat. Rev. Cancer 7 (2007) 573-584.

[53] Wolfe A, Shimer GH, Jr., Meehan T. Polycyclic aromatic hydrocarbons physically intercalate into duplex regions of denatured DNA, Biochemistry 26 (1987) 6392-6396.

[54] Uma Maheswari P, Palaniandavar M. DNA binding and cleavage properties of certain tetrammine ruthenium(ii) complexes of modified 1,10-phenanthrolines - effect of hydrogen-bonding on DNA-binding affinity, J. Inorg. Biochem. 98 (2004) 219-230.

[55] Zhou CY, Zhao J, Wu YB, Yin CX, Pin Y. Synthesis, characterization and studies on DNA-binding of a new cu(ii) complex with n1,n8-bis(1-methyl-4-nitropyrrole-2carbonyl)triethylenetetramine, J. Inorg. Biochem. 101 (2007) 10-18.

[56] Zhang LW, Wang K, Zhang XX. Study of the interactions between fluoroquinolones and human serum albumin by affinity capillary electrophoresis and fluorescence method, Anal. Chim. Acta 603 (2007) 101-110. 


\section{Figure captions}

Fig.1. Schematic illustration of the cytotoxic pathway and inactivation of platinumbased drugs.

Platinum drugs can enter cells using either copper transporter CTR1 or a passive diffusion mechanism. The reaction of platinum complexes with thiol-containing molecules outside and inside of cells results in their inactivation and resistance development. Also inside cells, the complex deactivation may occur enzymatically. In addition, both inactivated and functional complexes can be effluxed with the action of specific membrane transporter proteins (e.g. copper exporters ATP7A or ATP7B and glutathione S-conjugate export ATPase GS-X). Only functional fraction of Pt complexes can efficiently induce DNA damages. While the failed attempts of DNA repair system to eliminate these damages result in cell apoptosis, successful DNA repair challenges cause cell survival.

Fig.2. Chemical structure of the synthesized binuclear Pt (II) complexes.

\section{Fig.3. Anticancer activity of the synthesized binuclear Pt (II) complexes}

$\mathbf{A}$ and $\mathbf{B}$ respectively represent the growth inhibitory activity of the synthesized complexes against Jurkat and MCF-7 cancer cell lines. The tumor cells were incubated with varying concentrations of each complex for $24 \mathrm{~h}$ (upper panel) and $48 \mathrm{~h}$ (lower panel). The growth inhibitory activity was assessed using MTT assay as designated in the experimental section. The differences were regarded as significant at $(*) \mathrm{p} \leq 0.05$. 
Fig.4. AO/EB staining of Jurkat cancer cells after incubation with the synthesized binuclear Pt (II) complexes.

To perform AO/EB staining, the cancer cells with density of $2.5 \times 10^{4}$ cells/well were incubated for $6 \mathrm{~h}$ with the $\mathrm{IC}_{50}$ value of each Pt (II) complex. Then the cells were collected, washed with PBS and stained with AO/EB fluorescent dyes. A) The images were taken with a fluorescence microscope, using magnifications 100 (a), 200 (b) and 400 (c and d). Also, L, AP, LA and N, respectively stand for the live, apoptotic, late apoptotic and necrotic cells. B) Approximately 300 cancer cells were counted and the percentage of live, apoptotic and necrotic cells were calculated. The cancer cells were treated with each Pt complex at corresponding $\mathrm{IC}_{50}$ value for 2, 4, and 6 h. C) The activity of Caspase-3 was measured using an appropriate chromogenic substrate (Ac-DMQD-pNA). Also the bars represent mean $\pm \mathrm{SD}$ of three independent determinations.

Fig.5. The UV-Vis absorption spectra of the interaction of binuclear Pt (II) complexes with DNA and purine nucleotides.

A) The absorption spectra of hsDNA $(50 \mu \mathrm{M})$ were collected in the presence of increasing concentrations of each Pt (II) complex $(0-30)$ at $25^{\circ} \mathrm{C}$, in $\mathrm{TN}$ buffer. The arrow indicates absorbance changes upon increasing concentration of the complexes. B) The absorption spectra of each complex $(20 \mu \mathrm{M})$ were obtained with increasing concentrations of AMP and GMP $[\mathrm{ri}=$ complex/DNA $=0,0.5,1,1.5,2,2.5,3]$ at $25{ }^{\circ} \mathrm{C}$ in $\mathrm{TN}$ buffer. The arrow indicates variation in the absorption profile upon increasing concentrations of each purine nucleotide. 
Fig.6. Circular dichroism analysis of the interaction between binuclear Pt (II) complexes and DNA.

The CD spectra of hsDNA $(80 \mu \mathrm{M})$ were collected in $\mathrm{TN}$ buffer with increasing concentrations of each Pt (II) complex at the following stoichiometric ratios: $\mathrm{ri}=\mathrm{Pt}$ complex/ $[\mathrm{DNA}]=0.0,0.03,0.06,0.12$

Fig.7. The fluorescence analysis of interaction between binuclear Pt (II) complexes and DNA.

A) The fluorescence titration curve of EB-DNA $([\mathrm{EB}]=40 \mu \mathrm{M}$, [DNA] $=40 \mu \mathrm{M})$ in the presence of each complex $([\mathrm{Pt}$ complex $]=0-32 \mu \mathrm{M})$ performed in $\mathrm{TN}$ buffer, as the excitation wavelength was $546 \mathrm{~nm}$ and the emission spectra were collected between 550 and $700 \mathrm{~nm}$. B) The fluorescence titration curves were collected at a fixed concentration of Pt (II) complexes $(1 \mu \mathrm{M})$ with various concentrations of DNA $(0-30 \mu \mathrm{M})$. The excitation wavelength kept constant $(260 \mathrm{~nm})$ and the emission spectra were recorded between $500-550$ $\mathrm{nm}$, in $5 \mathrm{mM}$ TN buffer $\mathrm{pH} 7.4$.

Fig.8. The viscosity measurement of DNA in the presence of synthesized Pt (II) complexes.

The viscosity curves of hsDNA $(100 \mu \mathrm{M})$ were collected in the presence of varying concentrations of each Pt (II) complex $\left(\mathrm{r}_{\mathrm{i}}=[\right.$ complex $\left.] /[\mathrm{DNA}]=0,0.02,0.04,0.06,0.08\right)$ at 25 ${ }^{\circ} \mathrm{C}$. The experiments were done in the TN buffer

Fig.9. The molecular docking analysis of interaction between DNA and the synthesized Pt (II) complexes.

The molecular docking simulation was done with the optimized structures of the Pt (II) complexes and DNA using Hex 8 software. 
Table 1. The IC50 ( $\mu \mathrm{M})$ values of the Pt (II) complexes after incubation with cancer cells.

\begin{tabular}{ccccc}
\hline Cell line & \multicolumn{2}{c}{ Jurkat } & \multicolumn{2}{c}{ MCF-7 } \\
\hline Pt complex $(\boldsymbol{\mu M})$ & $24 \mathrm{~h}$ & $48 \mathrm{~h}$ & $24 \mathrm{~h}$ & $48 \mathrm{~h}$ \\
\cline { 2 - 5 } $\mathbf{1}$ & $5.00 \pm 0.46^{\mathrm{a}}$ & $3.80 \pm 0.47$ & $28.61 \pm 0.17$ & $13.49 \pm 0.89$ \\
$\mathbf{2}$ & $22.36 \pm 0.78$ & $12.37 \pm 0.91$ & $26.98 \pm 0.10$ & $18.21 \pm 0.31$ \\
Cisplatin & $78.33 \pm 11.20$ & $19.8 \pm 8.09$ & $69.78 \pm 1.13$ & $46.80 \pm 1.37$ \\
\hline
\end{tabular}

${ }^{\mathrm{a}}$ Standard deviation of the IC50 values.

Table 2. The binding constant values of the Pt (II) complexes with purine nucleotides.

\begin{tabular}{ccc}
\hline $\mathbf{K}_{\mathbf{b}}\left(\mathbf{M}^{-\mathbf{1}}\right)$ & $\mathbf{1}$ & $\mathbf{2}$ \\
\hline $\mathbf{5}^{\prime}$-AMP & $1.5 \times 10^{4}$ & $0.6 \times 10^{4}$ \\
$\mathbf{5}^{\prime}$-GMP & $2.6 \times 10^{4}$ & $0.9 \times 10^{4}$ \\
\hline
\end{tabular}

Table 3. The binding constant and number of binding site of Pt (II) complexes with DNA.

\begin{tabular}{ccc}
\hline Pt complex & $\mathbf{1}$ & $\mathbf{2}$ \\
\hline $\mathbf{K}_{\mathbf{b}}\left(\mathbf{M}^{-\mathbf{1}}\right)$ & $18.66 \times 10^{5}$ & $9.52 \times 10^{5}$ \\
$\mathbf{n}$ & $1.365 \pm 0.152$ & $1.079 \pm 0.042$ \\
\hline
\end{tabular}




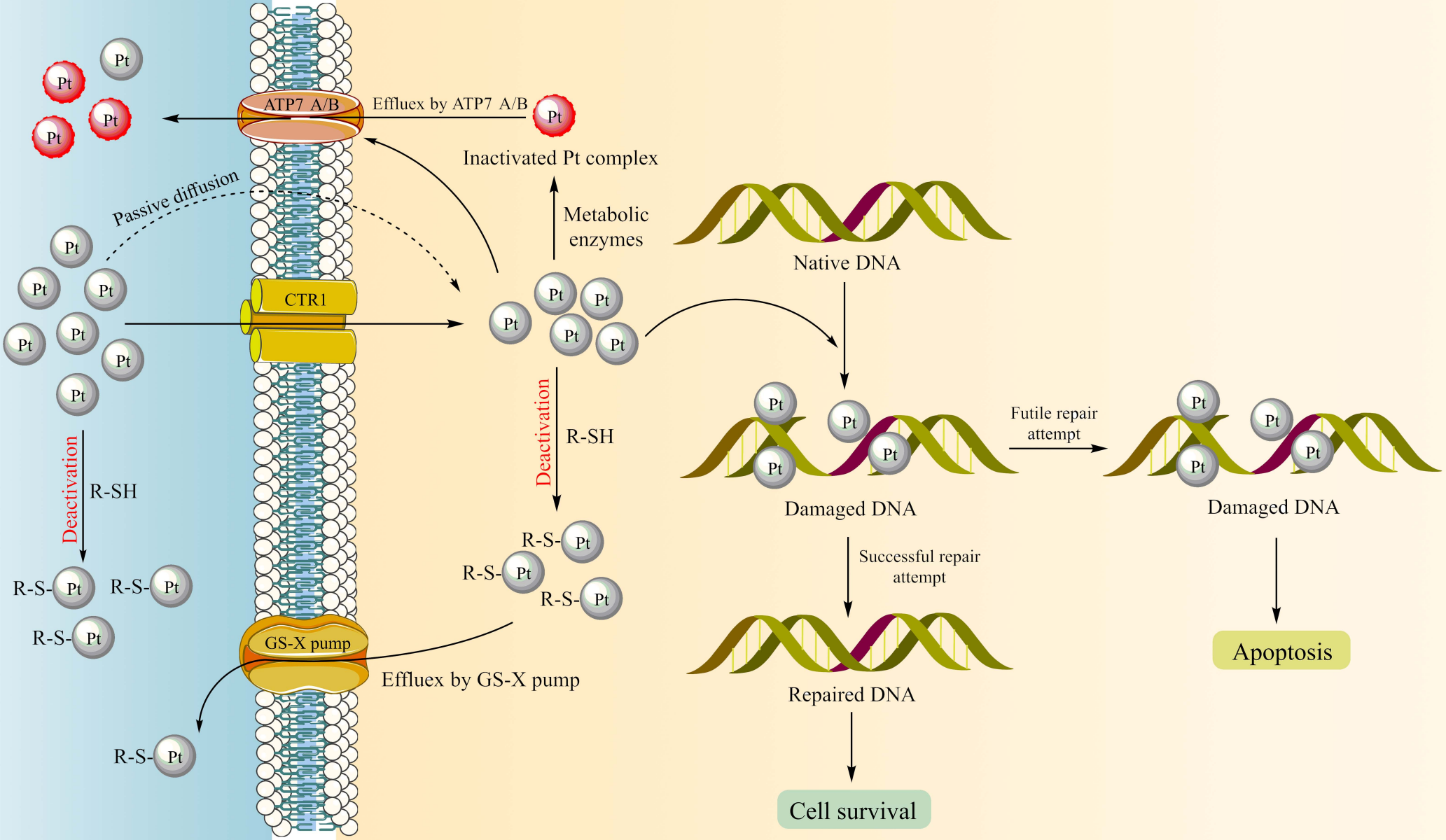




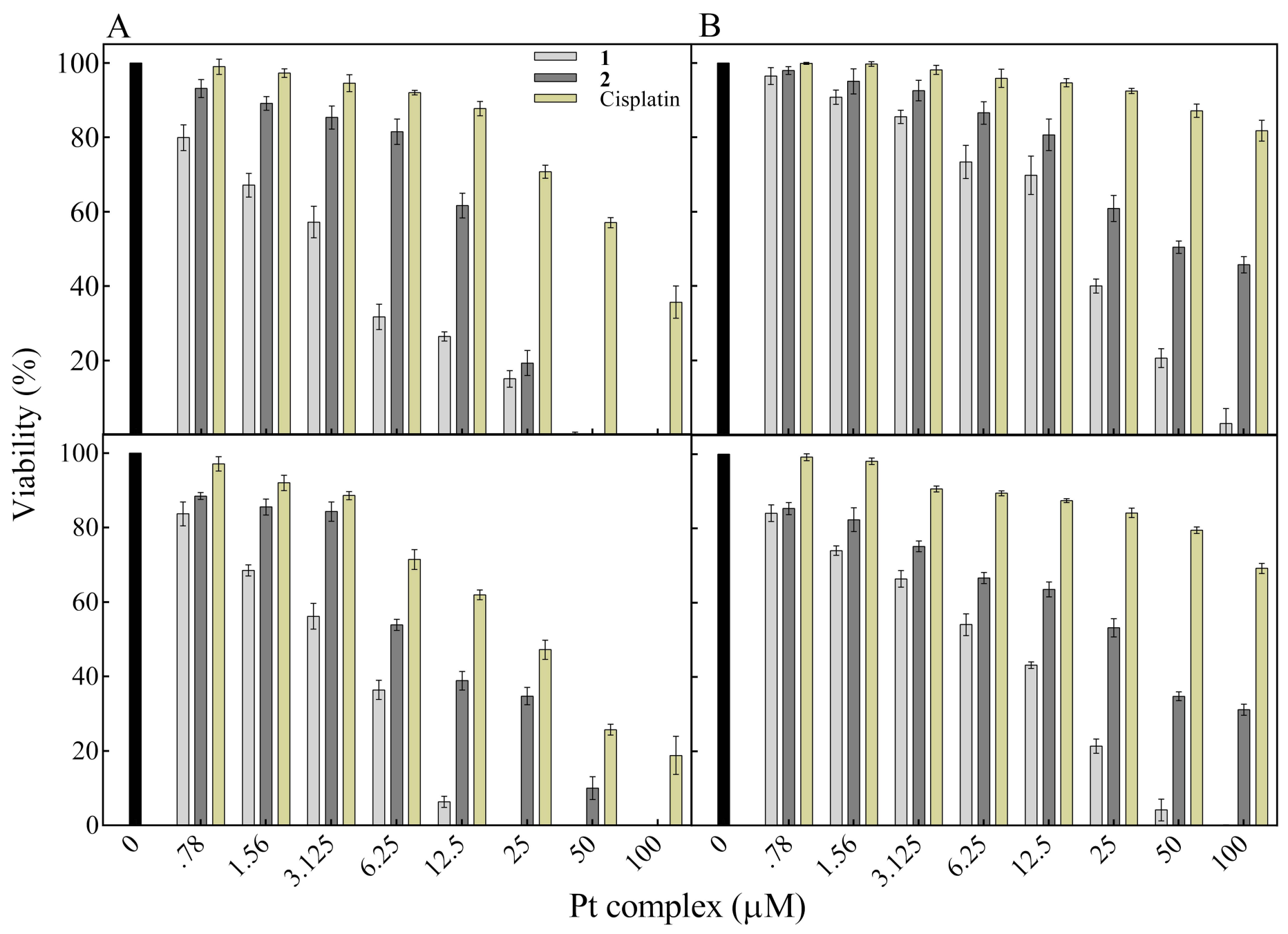




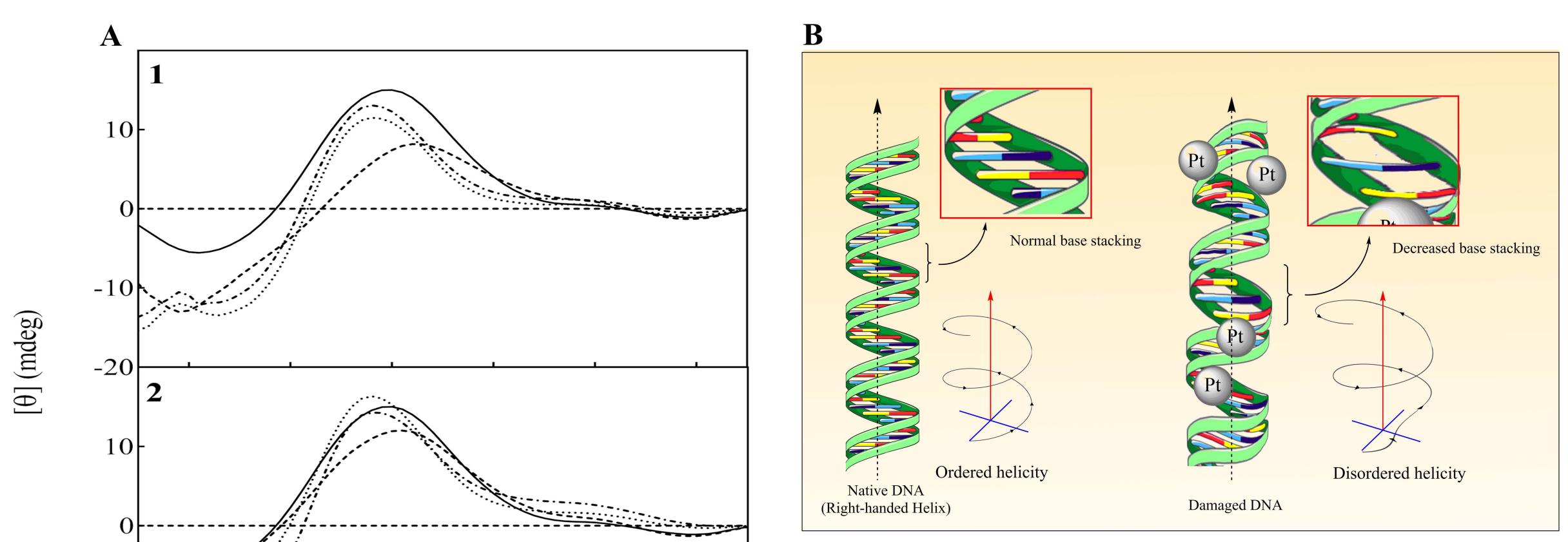

Negative CD signal $\equiv$ Helicity

Positive $\mathrm{CD}$ signal $\equiv$ Base stacking

$\mathrm{Pt} \equiv \mathrm{Pt}$ complex

Wavelength (nm) 


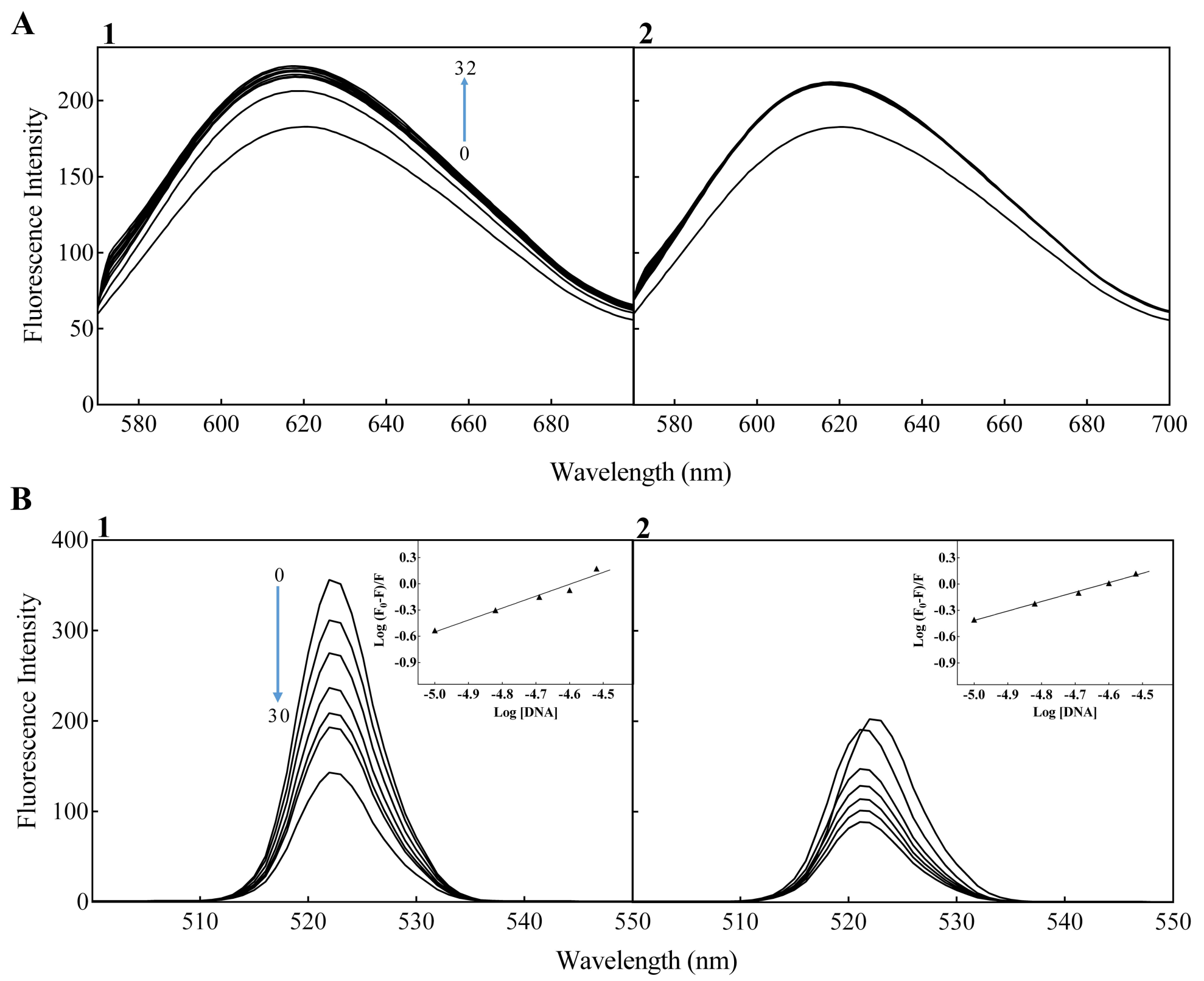




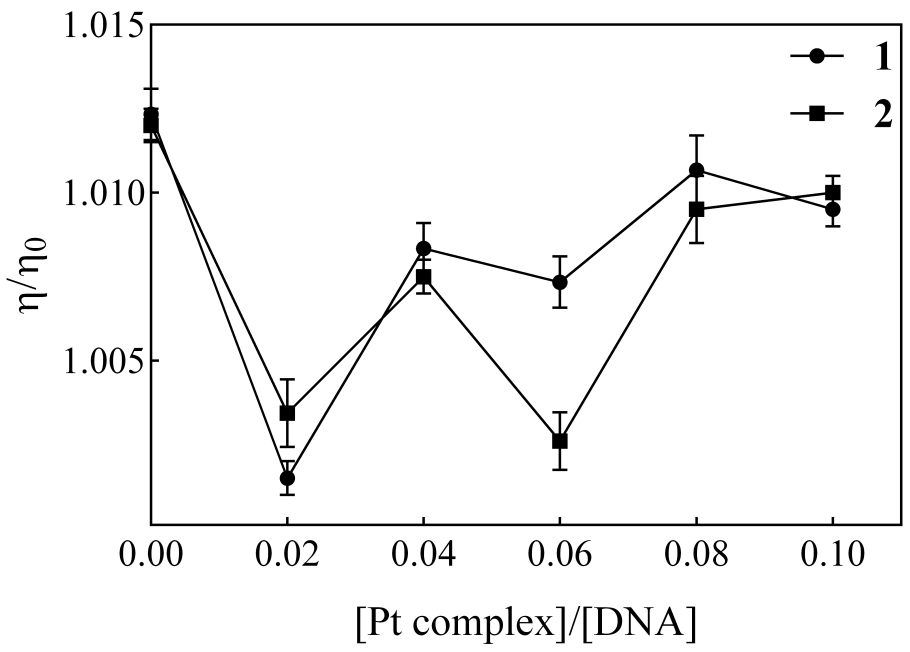



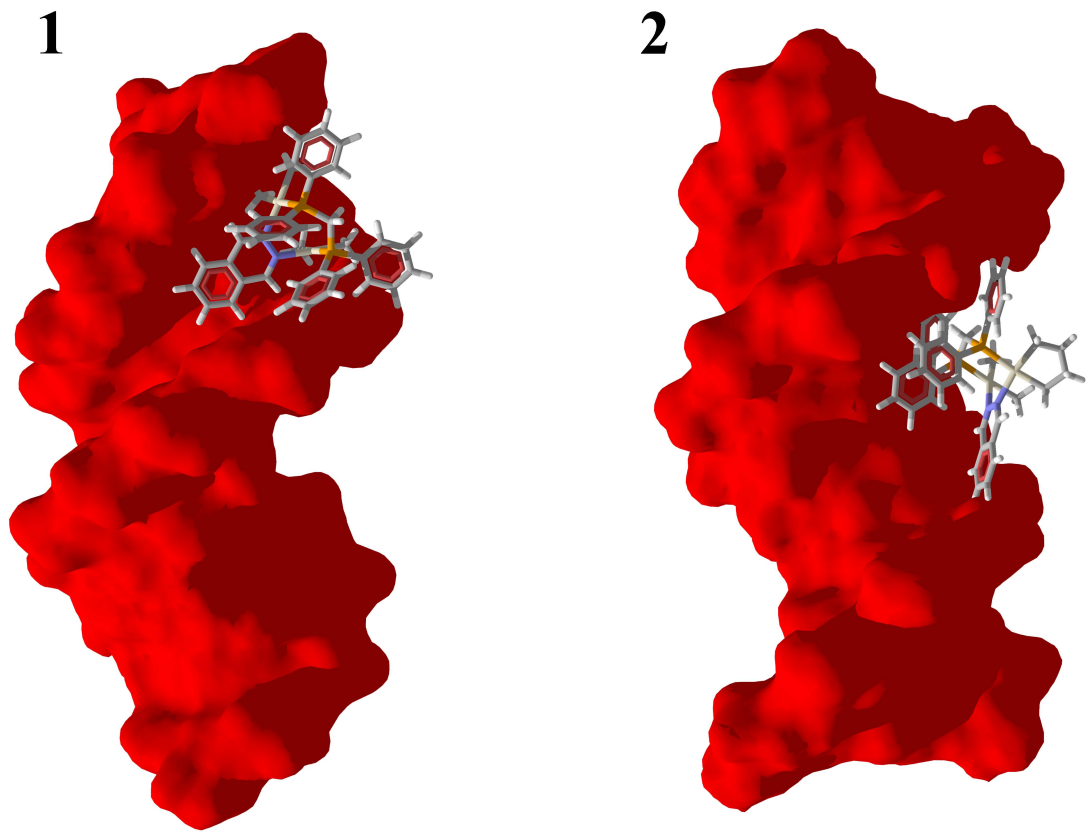


\section{Anticancer activity assessment of two novel binuclear platinum (II) complexes.}

Mohammad Bagher Shahsavani ${ }^{1,2}$, Shamseddin Ahmadi ${ }^{1}$, Marzieh Dadkhah Aseman ${ }^{3}$ S. Masoud Nabavizadeh ${ }^{3}$, Mehdi Rashidi ${ }^{3}$, Zahra Asadi ${ }^{3}$, Nasrollah Erfani ${ }^{4}$, Atieh Ghasemi ${ }^{5}$, Ali Akbar Saboury $^{5}$, Ali Niazi ${ }^{6}$, Aminollah Bahaoddini $^{7}$, Reza Yousefi ${ }^{2} *$

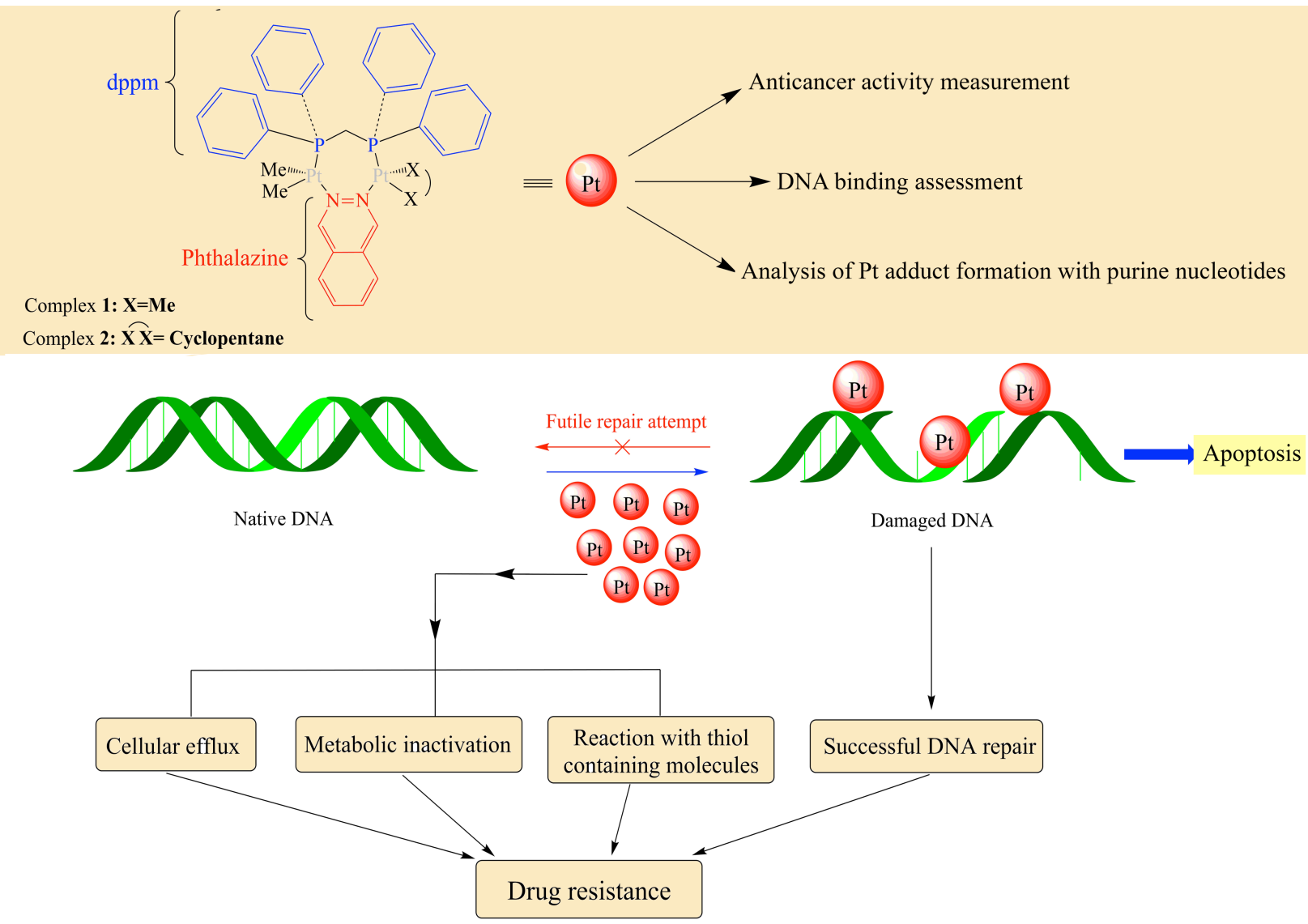

